\title{
EXAMINATION OF RELATIONSHIP BETWEEN ENTREPRENEURSHIP CHARACTERISTICS AND TYPE A PERSONALITY
}

\author{
Erkan BìL \\ Çanakkale Onsekiz Mart University / TURKEY, E-mail: erkanbil@comu.edu.tr
}

Metin SAYGILI

Sakarya University / TURKEY, Phd. Student, E-mail: mtnsaygili@gmail.com

\begin{abstract}
The purpose of this study is to examine the relationship between type A personality structure and entrepreneurship characteristics. For that purpose, a research was conducted on students who are being educated in a public university in Turkey and the will to succeed, determination, practical intelligence, innovation, independence and self-confidence, which make up the entrepreneurship characteristics, and type A personality characteristics is studied. In the literature screening conducted in relation to the research subject, no sufficient number of studies were encountered which dealt with type A personality structure and entrepreneurship characteristics. In this regard, it is considered that the research will have a great contribution for both the academicians and implementers who are working in the field, as well as for the literature.

Quantitative research method was adopted and used for the research. Face to face survey technique is used in this research for data collection. In the research. "Entrepreneurship Characteristics" scale was used based on the study carried out by Solmaz et al. (2014) in order to measure entrepreneurship characteristics. In order to determine type A personality characteristics, 8 rated Likert type scale and 7-article short form included in the studies conducted by Aktaş (2001), Erdoğan and Zengin (2012) and Yıldiz and Özsoy (2013) and developed by Bortner (1966) were used. The universe of the study
\end{abstract}




\section{$\int\left(\begin{array}{c}\text { Journal of Life } \\ \text { Economics }\end{array}\right.$}

comprises the students of management faculty who are being educated in 2016 - 2017 academic calendar of a public university. For collecting he data related to the research, easy sampling method on 247 students was adopted, face to face survey was applied and 14 of the surveys were not included in the data set since these were not completely filled out. Data obtained from 233 participants was analyzed in SPSS 21.0 statistical analysis package software. In the research, definitive statistics were used in order to demonstrate the general characteristics of the sample; correlation analysis was used in order to examine the relationship between will to succeed, determination, practical intelligence, innovation, independence and self-confidence, which constitute the characteristics of entrepreneurship and type A personality, and reliability analysis was conducted towards scales used in the research.

Results of the correlation analysis carried out demonstrate that there is a $r=0,647, p=0,001$ level statistically significant, positive direction and medium level relationship between type A personality structure and entrepreneurship characteristics. Besides, the dimensions of practical intelligence $(r=0,517 ; p=0,000)$, will to succeed $(r=0,547 ; p=0,000)$ and independence $(r=0,508 ; p=0,000)$ which constitute entrepreneurship characteristics, have a statistically significant, medium level and positive relationship with type A personality structure. The relationship between innovation $(r=0,398$ $p=0,000)$ determination $(r=0,497 ; p=0,000)$ and self-confidence $(r=0,501 ; p=0,002)$ dimensions and type A personality structure was found to be statistically significant, positive direction and medium level.

Keywords Type A Personality, Personality Characteristics, Entrepreneurship, Entrepreneurship Characteristics

JEL Codes: L26, M10

\section{INTRODUCTION}

The concept of entrepreneurship has started to come to the agenda particularly following the industrial revolution and as the technological advancement got further pace, the importance of entrepreneurship started to boost up. Entrepreneurs who succeed create new jobs and create new employment opportunities and thus have a great contribution in the economy. Entrepreneurship, which today started to come to the agenda as essential economic revenue sources of the countries, is started to be taught as courses in the schools and as part of training in various organizations and the spirit of entrepreneurship is tried to be awakened in the individuals.

As a result of researches conducted in relation to entrepreneurship, typical characteristics of individuals having entrepreneur characteristics were determined with certain frameworks and the characteristics pertinent to the entrepreneur person were roughly drawn. The concepts of entrepreneur and entrepreneurship were used to have the same meaning due to habitual use and similarity of both words, however, as a result of the studies conducted, it was demonstrated that these two are different concepts. To put it roughly, an entrepreneur is a person who sees the opportunities and acts accordingly, entrepreneurship is the general name given to the advance that is taken. When we evaluate entrepreneurship as a process and the entrepreneur as the owner of such process, different definitions are made in the literature in order to reveal different perspectives in relation to the concepts of entrepreneur and entrepreneurship (Arıkan, 2004:46). In other words, entrepreneurs undertake important roles in the pace of societies towards modernity and they not only have a contribution in the economic life, but also they contribute in improving the quality of social life. Entrepreneurship, which appears before us as the process in which the entrepreneurs put these roles into life, covers the action of producing goods and services by bringing together the production factors such as labour, technology, capital and natural resources. 
When the existing studies in the literature are examined, the characteristics of entrepreneur persons were identified and the definitions were made within this framework. When we look at the basics of different personality characteristics, personality is defined as the characteristics that are unique to a person and it is stated that every person has a unique characteristic. In a definition made by Tutar (2015), personality is created by such elements as mood, character and capabilities, and that it could be spoken of personalities equal to the number of human beings. Moving on this notion, it will not be accurate to put entrepreneurship into definitive patterns. However, pursuant to scientific studies, certain characteristics are defined to pertain to certain people within certain framework and persons who bear all or part of these characteristics were expressed to be individuals having entrepreneur character.

\section{CONCEPTUAL FRAMEWORK}

\subsection{Entrepreneurship}

Numerous studies have been conducted on the concept of entrepreneurship and different definitions were given by different researchers by emphasizing the different characteristics of entrepreneurship. Since entrepreneurship is a multi-faceted concept, the researchers tended to make definitions towards the works they have been conducting. When the definitions in the existing literature are examined, it could be seen that there are certain common aspects in different definitions towards entrepreneurship. Orienting towards what is new and different and carrying out studies towards that field as well as using the opportunities are considered as the fundamental characteristics of entrepreneurship.

The concept of entrepreneurship has derived from the word "entrepreneurship" which in French means fulfilling the needs and desires by launching a business and through innovation, and it was started to be used in different areas and in different meanings (Binks and Vale,1990:119;ref.Aksöz et al.,2012). Entrepreneurs have a significant function for the development and progress of a country. Regardless of whether the efforts of entrepreneurs succeed or not, they have contributions in the country economy and are important for the sake of progress of a country. Since the concept of entrepreneurship is in direct relation with the concepts of economy and technology, the importance of entrepreneurship for the progress and development of a country is undeniable. According to the definition made by Yilmaz and Sünbül (2009) "Entrepreneurs are the persons who undertake the motor function of the progress and development power of a country". As it could be understood from this definition, the entrepreneur persons have an undeniable importance.

There are ongoing discussions on whether the personality structures of the individuals, or social environment or the trainings received in relation to entrepreneurship has more effect compared to other on the appearance of entrepreneurship. At this dimension of the subject, to speak briefly on the opinions of researchers who emphasized personality as required by the general framework of our study, researchers who emphasize the importance of personality suggest that entrepreneurship has more risk taking, need to succeed and determination characteristics.

Some definitions made in relation to entrepreneurship which are included in the literature could be mentioned as follows (Ören and Biçkes,2011:71; Yıldırım et al.,2011:193; Yılmaz and Sünbül.,2009:21; Özdemir et al.,2016:124; Bernstein, 2011;ref.K1lıç et al.,2012:425). 
Table1. Definitions of Entrepreneurship

\begin{tabular}{l|l}
\hline Author & \\
\hline Ronstadt (1984) & \\
\hline $\begin{array}{l}\text { Stevenson, Roberts and } \\
\text { Gousbeck } \\
\text { (1985) }\end{array}$ & \\
\hline
\end{tabular}

Hisrich and Peters (1989)

Shane and Venkataraman (2000)

\section{Definition}

Entrepreneurship is the dynamic process of a richness established which continuously increases

Entrepreneurship is the orientation of individuals towards other alternative opportunities other than the resources that it has.

Entrepreneurship is the process of a valuable difference created over time and efforts; it is the estimation of accompanying financial, psychological and social risks and receiving monetary gift and personal satisfaction.

Entrepreneurship is defined as the relationship between the existence of profitable opportunities and the existence of entrepreneur individuals.

It is the common name for the behavioral and intellectual actions demonstrated by the entrepreneur, for the organization he/she created and the outputs as a result of all these.

Entrepreneurship is creativity, innovation, chasing after opportunities and taking risk, in addition to "converting the intellectual labor of human beings into economic value".

Entrepreneurship covers the act of creating goods and services by bringing together the production factors which are counted as labor, technology, capital and natural resources.

It is process of continuously creating new market opportunities for products and services, creating

Noruzi et al. (2010) innovations which could respond the needs of the day in products and services, and sharing these innovations with the customers.

Entrepreneurship is to protect innovation in products and processes within the framework of social benefit, to

Lee and Hsieh (2010) undertake risk, to develop up to date strategies and policies in accordance with environmental conditions.

Entrepreneurship is a person who recognizes the gaps and

Karahan and Ulusoy (2010) opportunities that occur in economy and in the market, converts these into business idea and establishes a commercial enterprise.

Entrepreneurship is the person who plans the work with a capability to make assumptions about the resources,

Ceylan (2012) coordinates human resources and ensures processing of inputs and presents the output obtained to the consumers so as to earn profits.

Source: Ören and Biçkes,2011:71; Yıldırım et al.,2011:193; Yılmaz and Sünbül,2009:21; Özdemir et al. 2016:124; Bernstein,2011;ref.Kılıç et al.,2012:425 
When we look at the definitions made in relation to entrepreneurship, generally an entrepreneur is a person who could take risk, bring scarce resources together, has a different view point and sees what could not be seen by all. It is of no doubt that every entrepreneur wants to reach success towards the work for which he/she is an entrepreneur and engages in the work by taking risk, with the idea of becoming successful. Entrepreneurs do not easily give up against failure and continue to work with full efforts. In the researches that are conducted in relation to the issue, it was found out that the entrepreneurs could make plans towards future, have a leadership personality, have a developed analysis capability, could make decisions rapidly, strong against stress, innovative and creative (Bozkurt et al.,2012; Balaban and Özdemir,2008; Seydinbekuli et al.,2015:44).

\subsection{Entrepreneur}

Despite the fact that there are numerous researches and explanations on the concepts of entrepreneur and entrepreneurship, it is not possible to speak about a common definitions on which there is an agreement (Koh,1996:13). Ören and Biçkes state that the reason for this disagreement is that both of the concepts have multi-dimensional characteristics and they are included within a broad framework (Ören and Biçkes,2011:70). The concept of entrepreneur traces back to old times as regards its roots and it is a multidimensional concept. The concept of entrepreneurship is handled by many disciplines such as management, foreign trade, economics, business administration and psychology.

As we have seen above (Table 1) in the definitions that are made in relation to the concept of "entrepreneur" in addition to the definitions of entrepreneurship, we can have a detailed information in relation to these two concepts if we have a holistic approach. Some definitions made in relation to the concept of "entrepreneur" are as follows:

Table 2. Definitions of Entrepreneur

\begin{tabular}{|c|c|}
\hline Author & Description \\
\hline Binks and Vale (1990) & $\begin{array}{l}\text { It is defined as the person who has become expert in taking } \\
\text { healthy and prudent decisions in relation to collaboration of } \\
\text { scarce resources }\end{array}$ \\
\hline Titiz (1999) & $\begin{array}{l}\text { He is the person who use his capability of productivity in order to } \\
\text { reach beyond the situation which continuously exists. }\end{array}$ \\
\hline Emsen (2001) & $\begin{array}{l}\text { It is defined as the person who combines various production } \\
\text { factors, undertakes risk, establishes his/ her own business and } \\
\text { takes part in the production process and eventually aims at } \\
\text { earning profit. }\end{array}$ \\
\hline $\begin{array}{l}\text { Ireland, Hitt and Sirmon } \\
\text { (2003) }\end{array}$ & $\begin{array}{l}\mathrm{He} / \text { she is the person who identifies and uses the opportunities } \\
\text { which have not previously been recognized by anyone else. }\end{array}$ \\
\hline Ağca andYörük (2006) & $\begin{array}{l}\text { An entrepreneur is the person who follows the opportunities and } \\
\text { undertakes any type of risk for reaching his/her purpose when } \\
\text { he/she takes such opportunities. }\end{array}$ \\
\hline Top (2006) & $\begin{array}{l}\text { It is a concept which takes the individual as basis and emphasizes } \\
\text { the special capabilities, skills and mental capacities of the } \\
\text { individual, and it is the work of acting in order to construct } \\
\text { resources and capacities which could shape the future in terms of } \\
\text { strategic competition and creating value with thoughts and } \\
\text { actions. }\end{array}$ \\
\hline Yalçıntaş (2007) & $\begin{array}{l}\text { He/she is the person who takes risk by chasing after opportunities, } \\
\text { innovations and creativity in order to reach the economic value. }\end{array}$ \\
\hline
\end{tabular}




\begin{tabular}{l|l}
\hline $\begin{array}{l}\text { Karahan and Ulusoy } \\
\text { (2010) }\end{array}$ & $\begin{array}{l}\text { He/she is the person who determines a need, coverts it into } \\
\text { business idea and opportunity, undertakes the risks that could } \\
\text { arise and establishes a commercial enterprise. }\end{array}$ \\
\hline Bozkurt (2011) & $\begin{array}{l}\text { An entrepreneur is the person who brings the production factors } \\
\text { (labor, raw material, other assets) together by creating bigger } \\
\text { opportunities. }\end{array}$ \\
\hline Hattab (2014) & $\begin{array}{l}\text { An entrepreneur is the person who sees and evaluates business } \\
\text { opportunities, brings together required resources and acquires } \\
\text { benefits from these and launches the suitable action for being } \\
\text { successful. }\end{array}$ \\
\hline
\end{tabular}

Source: Karasakal et al., 2013:137; Yıldırım et al.,2011:192-193; Ören and Biçkes, 2011:71; Ekici,2016.

An entrepreneur could briefly be defined as the person who establishes an enterprise and who carries out the activities of this enterprise. In the researches conducted on entrepreneur persons, it was determined that there were many factors which come from birth and which orients them towards becoming entrepreneur in the process of formation of their personalities, as well as many external factors which were effective in the formation of entrepreneur spirit such as training and environment.

Today an entrepreneur is accepted as the person who engages in economic activities and who could create social benefit from these activities. An entrepreneur could be defined as the person who brings together the production activities, is responsible for finding market area for production and who has the ability to find the required financial resource.

It is another issue which is frequently emphasized in relation to the entrepreneur that the entrepreneur person has certain characteristics. Personal characteristics of an entrepreneur could be counted as risk taking, need for success, and having entrepreneur potential. .

\subsection{Entrepreneurship Characteristics}

Entrepreneurs act taking into account the possibility that they could fail before engaging in an entrepreneurship and the expectation for success also affects such characteristics as the financial power, ambition, energy, experience and will to succeed. These characteristics which significantly affect the entrepreneurship potential rely on the personal characteristics of the entrepreneur (Alpkan et al., 2002).

While the entrepreneur catches the opportunities which reveal the potential and evaluates these opportunities and demonstrates actually the work which he/she wants to realize with the feeling of success, he/she is also required to take into account his/her social environment and organize it (Ören and Biçkes,2011:74). The fact that the problems solving abilities of individuals who have entrepreneurship potential is high and they also have high level of effective hum interaction and convincing, make it easy for the entrepreneurs to organize their environments.

While the entrepreneurship potential could arise as a result of trainings that are received in relation to entrepreneurship, it may also arise in individuals who have the entrepreneur personality. Studies carried out demonstrate that the entrepreneurship potential increases in individuals who receive entrepreneurship training.

Hisrich and Peters (1992) defined the personal characteristics of a successful entrepreneur as follows: High level of desire for work, creative thinking, braveness, passion and determination, imagining power, being open and attentive to change, having the 


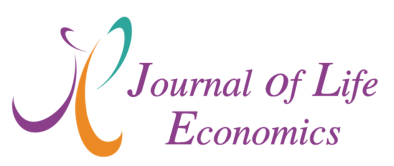

capability of making someone believe and convincing, capability of expressing oneself verbally and in writing, passion and excitement to complete a work, having managerial and leadership capacity. In addition to these characteristics, it is also expressed that entrepreneurship is also affected by the concepts of inner control focus, enduring uncertainty, risk taking, self-confidence and innovation (Bygrave and Minniti,2000).

Taking into account other definitions in the literature and explanations made in relation to the characteristics of entrepreneur personality, various different concepts arise. Since it is not possible to explain all of these concepts in relation to the issue, emphasis will be on will to succeed, determination, practical intelligence, innovation, independence and self-confidence, which are considered to be closely related to personality structures and this study.

\section{- Will to succeed}

Will to succeed could be expressed as one of the indispensable characteristics for an entrepreneur. Will to succeed could be defined as a motivating power which triggers the entrepreneur and gives him/ her the passion to work towards his/her purpose. Will to succeed is one of the fundamental determinants for conlcuding any works in a successful manner (Hansemark,2000:634).

Will to succeed, which significantly affects entrepreneur behaviors and which has a very important role to play in accomplishing the entrepreneur, provides the motivation which the entrepreneurs need for becoming successful and this is the reason for the high potential of entrepreneurs to demonstrate behaviors towards entrepreneurship compared to other individuals who do not have entrepreneur spirit (Koh,1996:14; Ören and Biçkes,2011:73).

Individuals with high will to succeed focus more on their targets in order to be successful, calculate the risks and tend to have risk taking tendency, and interpret the events according to the change potential. (Champoux, 1996:180;ref. Ceylan and Demircan,2002:4).

\section{- Determination}

One of the leading characteristics of an entrepreneur person is that he/she is determined. Since the entrepreneurs make investments towards the unknown, to create a new sector or to launch into a new sector, it is highly important that they are determined in the way they entered in order to succeed. Being determined and not being in hesitation in investments to be made, is highly important for reaching the targets. If the entrepreneur tends to orient towards other works and things rather than focusing on his/her own business, his/her efforts will give no results and its attempts will end up in failure.

\section{- Practical intelligence}

An entrepreneur person should have a practical intelligence. How the entrepreneur person benefits from the events, how he/she concludes the events and what sort of a lesson he/ she derives out of the events that occur, are an important factor for the entrepreneurship to reach success. No doubt that there is relationship between seeing the opportunities which no one could see and having a practical intelligence, which is always mentioned in relation to entrepreneurship. An entrepreneur person enters into an economic activity when he/she engages in an entrepreneur activity and it could be said that the risk exists always in the economic activities. Investing in an unknown subject or a market is always defined as highly risky. Brindley (2005) and Bozkurt and Erdurur (2013) define risk in economic life as the possibility of facing loss in decisions on which a potential benefit earning is based, due to the high uncertainty that exists in connection with the structure of the environment (Brindley, 


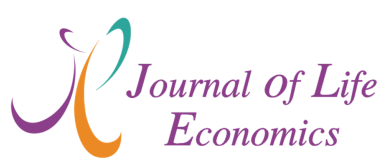

2005: 145;Bozkurt and Erdurur,2013:60). In this regard, the entrepreneur works for calculating and tolerating the risks with his/her practical intelligence and earn profit. The entrepreneur having a practical intelligence is important for the entrepreneurship to reach success.

\section{- Innovation}

Entrepreneur is a person who presents innovations and tries to reach success by putting innovation to the field. The term innovation is defined in general as developing a new product, entering into a new market, creating a new structure and engaging towards a new trend. An entrepreneur person should not be closed to innovation, be open to new things and closely follow new developments. As a matter of fact an entrepreneur exists with innovations, and the entrepreneurship occurs as a result of a new view, a new method, a new organization etc. It is not possible to engage in a new initiative by repeating the old and remaining closed to innovations. For that reason, entrepreneurs should be persons who are open to innovations and who chase after new things.

\section{- Independence}

It could be seen that individuals who have entrepreneur characteristics do not work under the order of others, have high emotions to work independently and act with the notion of having their own businesses. Individuals who have an entrepreneur spirit do not become happy by working in fixed and monotonous works and they tend to demonstrate something with their own efforts. Will for independence, which is an important factor for the enterprise to succeed, continuously triggers the individual who has an entrepreneur spirit and they demonstrate different things, engaging in initiatives to become boss of their own businesses.

\section{- Self-confidence}

The entrepreneur should first of all trust in himself/ herself and believe that he/she will end up with success. It is important for one who newly starts a business and who carries out he work to be determinant so as to reach to success. Since the entrepreneurs invest in the unknown, they need to be prepared against the problems they encounter or could encounter and should have belief that they could overcome the problem in question. An entrepreneur should believe that he/she could fulfil the requirements of the work when he/she starts the work, and continue his/her actions by making other people around him/her believe he will succeed. Since starting a new business also brings together the risk of failure, many people tell to the entrepreneur that his/her initiative will fail and he/she will lose time, so the entrepreneur should have full self- confidence in order to avoid such negative rhetoric and fulfill the initiative that he believes.

\subsection{Personality Structure}

Personality is the whole of characteristics unique to the individual which separate him/ her from others. Personality is evaluated as a whole of physical, mental and spiritual characteristics. When we speak about personality, we understand all of the characteristics of an individual such as emotions, thoughts and behaviors which make him/ her different from other people in addition to his/her objective and subjective aspects which are unique to $\mathrm{him} / \mathrm{her}$. In other words, personality could also be expressed as the sum of characteristics which make an individual himself/herself (Tutar,2013). There are many roles played by different factors ranging from genetic factors to social environment in the shaping of personality. Even the books read, films and TV programs watched by the person etc. are effective on the formation of personality. 


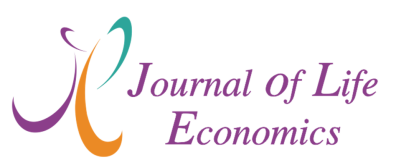

The personality of an individual affects his/ her whole life and habits. Persons are defined with personality characteristics while sustaining their lives. Although personality characteristics are expressed as qualities that are unique to individuals, it is possible to define personality characteristics within the framework of certain patterns, as it has been demonstrated by various researchers. For example, it is not possible to make a definition indicating the characteristics that an entrepreneur person should bear while stating the characteristics of an individual who has an entrepreneur character. These qualities expressed are defined in certain frameworks to categorize them such as personality characteristics. When we look at the studies conducted in relation to the issue, it is possible to define the personality type as a system which ensures understanding what the individuals do for which reason, as well as understanding the natural tendencies of individuals in their unique preferences (Balkıs,2003).

For researches that are conducted in relation to personality, different scales and different indicators are used and in such different uses scientific validity and reliability have been ensured. This situation arises from the fact that personality states for characteristics that are unique to people, which means that there are different characteristics equal to the number of people. In order to carry out scientific studies in relation to the subject, different researchers made different groupings and tried to put the personality characteristics into certain patterns. Since this study will focus more on the relationship between type A personality and entrepreneurship, the type A and B personality characteristics suggested by Meyer Friedman, who is a cardiologist, and Rosenman in relation to personality types will be emphasized.

Individuals demonstrating type A personality characteristics are sensitive against time and they have a hasty characteristic. They love competition, like working and they devote themselves to their works. Individuals who have type A personality generally walk fast, talk fast, and try to make several works at a time. Persons of such character could fall into stress very quickly and they could be stressful even under normal conditions (Lelord and Andre,1996) Individuals with type A personality characteristics are continuously in a rush and they always tend to do something. These kind of people generally fail in time management (Aytaç,2002).

Individuals demonstrating type B personality characteristics are not that much competitive and as opposed to individuals demonstrating type A personality characteristics, they are the ones who devote themselves less to their work and they are not in a rush with time. Individuals demonstrating type B personality characteristics have a more balanced and relax approach towards their work and social lives. Individuals with type B personality characteristic feel themselves safer. They are not perfectionists, they are not excessively ambitious, as opposed to those who demonstrate type A personality, they have a rather malleable and hard to get angry type of character (Durna,2005). Besides, people demonstrating this type of personality have a less exciting character and they do not engage in haste, are calm, not in rush, and use time a more comfortable way (Yurtsever,2009:65). Individuals demonstrating type B characteristic know how to enjoy the work they do, they work regularly and calmly (Güney,2000:446)

\subsection{Literature Scanning Towards Personality Structure and Entrepreneurship Characteristics}

When the literature on entrepreneurship is studies, it could be seen that the subject of personality has been the issue of many studies from past up to now from the point of view of the management science and entrepreneurship. When examined in this regard, it could be seen 




that there are researches in the literature which study the relationship between personality and personality characteristics and entrepreneurship. When considered from this aspect, it is possible to make derivations in relation to business and working areas by establishing relationship between personal characteristics of persons and their desire to become entrepreneurs, which should be done by academician who are dealing with the science of management, as well as implementers in the area and the entrepreneur persons themselves. Meanwhile these derivations make it possible to determine the characteristics of entrepreneur persons through personal characteristics and demonstrating their entrepreneur capabilities. Based on this notion, the following part generally evaluates the studies related to personality and entrepreneurship.

There are numerous studies which asserts that entrepreneurship is a form of activity which arises with the combination of various personality characteristics. Together with this, it could be understood that many researches which examine entrepreneurship up to day contained certain common concepts in their entrepreneurship characteristics. It is possible to list the characteristics commonly expressed in the literature in relation to entrepreneur personalities:

University students who are enrolled in higher education are considered as potential entrepreneurs. In the relevant literature, it is worth to note that there are numerous researches towards determining the entrepreneur personality characteristics and entrepreneurship trends of university students. It is noteworthy that this issue has become an intense focal point from the aspect of academicians. However, when the studies conducted in relation to entrepreneurship are examined, it could be seen that the researchers approach to the issue from different aspects.

In a high majority of studies conducted, the entrepreneurship trends of university students have been tried to be determined (Balaban and Özdemir,2008; Avşar,2007; Fidan and Sünbül,2009; Doğaner and Altunoğlu,2010; Bozkurt,2006; Akyüz et al.,2006; Fidan and and Çiftçi, 2010; İrmiş and Barutçu,2012; Keleş et al.,2012; Bilge and Bal,2012). In addition to these studies, there are some others which deal with the relationship between entrepreneurship and individual and cultural characteristics (Çarıkçı and Koyuncu,2010). Also the literature related to factors that affect entrepreneurship trends (Örücü,2007; Orman,2009) is also among the issues of research.

When the literature is researched, there could be seen researches which are directed towards determining the entrepreneurship characteristics of students who are in higher education in different countries (Koh,1996; Wang and Wong,2004; Franco et al.,2010; Linan et al.,2010). In a study conducted on 54 MBA students in Hong Kong, it was determined that the trend towards entrepreneurship was highly correlated with the need to succeed, need for independence, tolerance against uncertainty, risk taking trend, self- confidence and being innovation (Koh,1996).

There are researches towards determining the entrepreneur characteristics and entrepreneurship trends of students who are in higher education in Turkey. When the results of these researches are examined in general, it could be demonstrated that a high majority of students who are receiving higher education in Turkey have a desire to do their own business in the future. Results of the study conducted by Bozkurt (2006) among undergraduate students who are enrolled in economics and administrative sciences in Sakarya University, demonstrated that the students want to do their own businesses in the future. Studies by İrmiş and Barutçu (2012) also highlight the same results. In the study in question, the rate of students who want to establish their own businesses was determined as $76.7 \%$. In another 


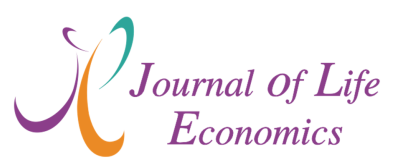

research conducted in this area, İrmiş (2003) demonstrated that, in his study conducted on entrepreneurship trends in university students in Bishkek, a high majority of students of $44.8 \%$ intended to establish their own businesses. Akyüz et al. (2006) demonstrated in the study they conducted in Rize among 363 high school and university students that $33.3 \%$ of the students aimed at becoming a high level manager in a company after graduating from the school, and $66.7 \%$ indicated that they wanted to establish their own businesses.

İşcan and Kaygın (2011) also determined in their study conducted among undergraduate students being educated in Kirikkale and Kars that the rate of students who indicated their possibility to establish own business after graduating the school to be $50 \%$ was $28.8 \%$. In many researches conducted, it could be understood that the university students have a significant desire to establish their own business. However, in some of researches conducted on university students, it could be seen that results are obtained which are contrary to the findings above. In a research conducted by Balaban and Özdemir (2008) on Management Department students of Sakarya University, it was determined that only $21.4 \%$ of the students wanted to perform their own businesses in the future. Together with this, it was determined that a high portion of the students planned to worked in the private sector in the future (\% 52). On the other hand, in the study of İşcan and Kaygin (2011), it is demonstrated that, despite the high rate of students who want to have a business idea and who intend to establish their own businesses, the responses they gave to the question of the sector which they intend to work show that they do not want to engage in any entrepreneurship activity. As a consequence, almost all of the students (\% 91) want to work in a career position in public sector.

In numerous works that were conducted towards determining the entrepreneurship trends of university students, it was demonstrated that the trend for entrepreneurship was related to demographic factors such as gender, age and education. When the studies carried out are examined, it could be seen that there is a significant relationship in particular between gender and entrepreneurship. In this regard, it is possible to say that the boy students have more entrepreneurship characteristic compared to girl students (Avşar,2007; Cansız,2007; Orman,2009; Yılmaz and Sünbül,2009; Doğaner and Altunoğlu,2010; Bilge and Bal,2012) Another demographic element which affects entrepreneurship is the age group (Orman,2009). Bozkurt (2007) indicates that there is a tight relationship between age and entrepreneurship. Sinha's (1996) research supports this result.

A research was conducted by İbicioğlu et al. (2009) on students of Mehmet Akif Ersoy University Zeliha Tolunay Applied Technology and Management School, Veterinary and Training Faculty. 241 students attended this research which was carried out in 2009. The research studies whether the family factor has any impact on the formation of students' entrepreneurship type preferences and on the entrepreneur characteristics they have. It was determined that the demographic characteristic of parents and their living standards have an effect on the children having entrepreneur characteristics and on the entrepreneur type preferences. Besides, it could be said that students whose parents had a successful entrepreneurship process are more effective compared to those whose families have no relationship with entrepreneurship in relation to "risk taking" and "effective use of resources" characteristics.

In the research conducted by İpçioğlu and Taşer (2009) on the students in Management Department of Bilecik University and Dumlupınar University, a scale was applied on students which comprised such expressions as need to succeed, internal control, tendency to take risk, being innovative, self-esteem and showing tolerance against 


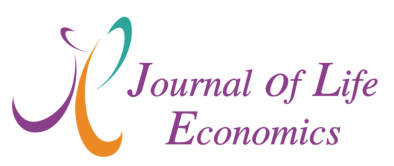

uncertainties, which are the sub-dimensions of entrepreneurship. They obtained significant differences at sub-dimensions "tendencies to take risk" "being tolerant against uncertainty" and "self-esteem" of entrepreneurship.

A survey was applied by Bozkurt (2006) as part of the study titled "Importance of Personality Characteristics in Entrepreneurship Tendency" in order to measure what type of impact the personality characteristics and demographic characteristics have on the entrepreneurship tendencies of students in Economics and Administrative Sciences Faculty of Sakarya University, As a result of the study, despite the fact that the mass feels a need for success, they are uncertain in relation to risk taking, tolerance against uncertainty, innovation, self-esteem and control center. Besides, when it is examined if there is any difference in relation to gender, no significant difference was found in terms of risk taking and uncertainty tolerance among men and women. In addition to this, despite the fact that they have a low level in terms of bearing the characteristics of entrepreneurship personality, they are found to be in tendency to establish their own businesses in the future and they consider to realize this with their personal savings. Besides, they tend to work in a prestigious work in private sector if they fail to establish their own businesses.

In their studies conducted on the students of Balıkesir University Bandirma Faculty of Economics and Administrative Sciences Management Department, Kılıç, Keklik and Çalış (2012) tried to determine the entrepreneurship characteristics of university students. According to the findings they obtained, it was concluded that boys were more innovative compared to girls.

In his study, Doğan (2013) aimed at determining the factors which affect entrepreneurship trends of senior students in the faculty of economics/ economics and administrative sciences of some universities and researching the impact of main demographic characteristics on these factors. As a result of statistical analysis of the data obtained, the factors of being reliable and undertaking responsibility, risk taking, being outwards, being open to criticism, being conservative and in harmony, being emotional and imaginary, being tense and having the ability to forecast had an impact on the entrepreneurship tendencies; and the factors of being ambitious and competitive, difficulty to establish new business, avoiding risk, establishing and operating own risk, family support and humanism factors had impacts on the statements related to entrepreneurship trend.

A survey was applied by Özdemir et al. (2016) in the occupational school of a public university in order to study the impact of risk taking tendency and need to success, which are among the personality characteristics of students, on the entrepreneurship potential, and it was concluded in the research conducted that the need to success and risk taking behavior had positive impact on the entrepreneurship potential.

When the literature scanning done in relation to the research subject is examined, it could be seen that there were studies covering the entrepreneurship tendency, entrepreneurship potential and demographical characteristics. However, the fact that there were no sufficient number of studies which studied the entrepreneurship characteristics of Type A personality structure, points out that this research will have a significant contribution on the academicians and implementers who work in this field as well as to the literature.

\section{METHOD}

\subsection{Objective and Importance of the Research}

The purpose of this study is to examine the relationship between type A personality structure and entrepreneurship characteristics. The research is important in terms of 


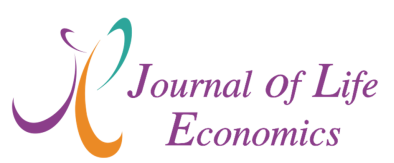

demonstrating the relationship between the entrepreneur aspects and characteristics of students who are potential entrepreneur candidates of future and the type A personality structure, and designing a model towards the impact of personality characteristics on entrepreneur activities.

\subsection{Sample and Data Collection}

The sample of the research comprises students who are in education in the management faculty of a public university. The data of the research was obtained through easy sampling method and face to face surveys with 233 students were determined on the basis of volunteerism. 247 of the questionnaires that were handled to the students to be filled out by them were returned, and 14 of these were kept outside assessment due to various shortcomings. A total of 233 questionnaires were taken into evaluation.

\subsection{Research Model}

The following model was developed in lien with the objective and assumptions to determine the relationship between "Type A personality structure" and "entrepreneurship", the dimensions and the aspect of the relationship. In the model, the relationship between type A personality and entrepreneurship was demonstrated. The basic assumption of relationship model between type A personality structure and entrepreneurship was that there is a statistically significant relationship between type A personality and entrepreneurship which comprises such sub-dimensions as will to succeed, determination, practical intelligence, innovation, independence and self- confidence, which emphasized the entrepreneur characteristics of people. For that purpose, a $\mathrm{H}_{1}$ hypothesis was established, which read as "there is a statistically significant relationship between type A personality structure and entrepreneurship characteristics".

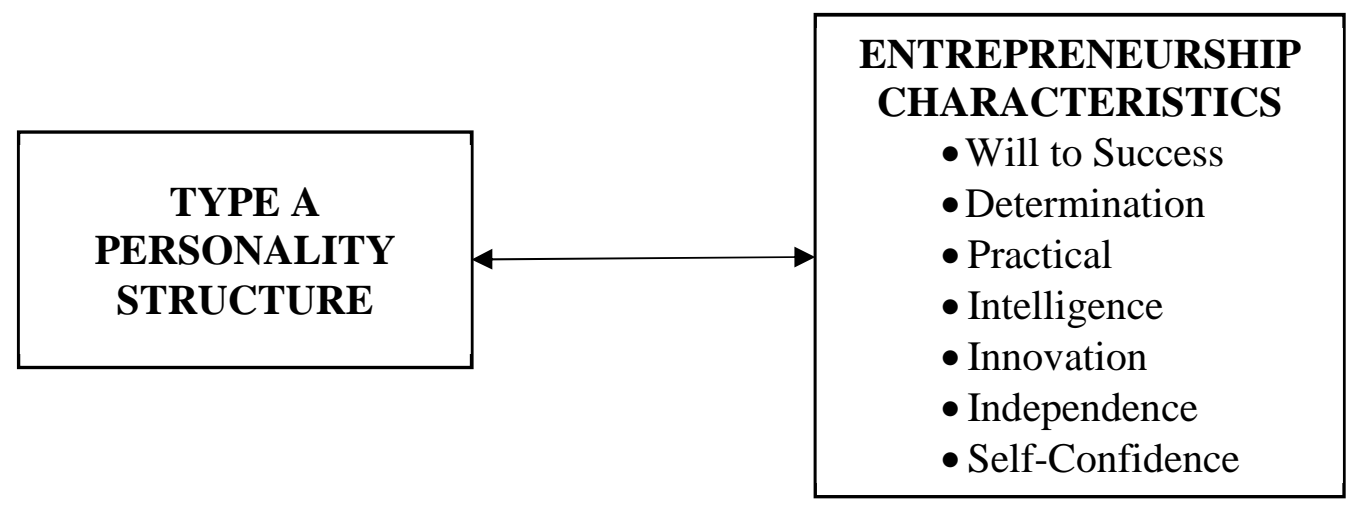

Figure 1. Research Model

\subsection{Scales Used in the Research}

In this research, in order to determine the entrepreneurship characteristics of participants, the studies of Summer (1998) and Brice (2002) were taken as basis. Besides, the scale which was adapted into Turkish taking into account the study which was carried out by Avşar (2007), was used benefiting from the study of Solmaz et al (2014). In this regard, the scale in question comprises the dimensions of will to succeed, determination, practical intelligence, innovation, independence and self-confidence. The entrepreneurship characteristics scale was used in the 
research after being adjusted according to the Likert type scale of 5 (1: Strongly disagree.........5: Strongly agree) comprising 22 statements.

In this study, in order to determine the characteristics of type A personality structures of participants, Short Form of Bortner Rating Scale) (SFBRS) was used, which was also used previously by Aktaş (200), Erdoğan and Zengin (2012) and Yıldız and Özsoy (2013). The short form of the scale in question is a scale comprising 7 statements of Likert type (8 degrees) and the median of the scale is 4.50 .

\section{DATA ANALYSIS AND FINDINGS}

\subsection{General Characteristics of the Participants.}

$\% 53,2$ of participants are women and \% 90,1 are aged between 17-22. \%54,5 of ages of participants is between 20-22 interval. When the monthly incomes of the participants are taken into account, more than half of the participants have an income of $1000 \mathrm{TL}$ and less $(\% 52,4)$.

\subsection{Will to Orient Towards Entrepreneurship}

Findings related to definitive statistics obtained in relation to wills of participants to orient towards entrepreneurship are as follows.

Table 3. Will to Orient Towards Entrepreneurship

\begin{tabular}{|l|c|c|}
\hline Which is the sector you want to work in following your graduation? & f & \% \\
\hline Public Sector & 44 & 18,9 \\
\hline Private Sector & 128 & 54,9 \\
\hline Family Business & 10 & 4,3 \\
\hline Own Enterprise & 51 & 21,9 \\
\hline $\begin{array}{l}\text { Has any of your family members established and managed his/ her } \\
\text { business? }\end{array}$ & $\mathbf{f}$ & $\mathbf{\%}$ \\
\hline Yes & 130 & 55,8 \\
\hline No & 103 & 44,2 \\
\hline Do you plan to establish your business in the future? & f & $\mathbf{\%}$ \\
\hline Yes & 161 & 69,1 \\
\hline No & 72 & 30,9 \\
\hline
\end{tabular}

Findings in Table 3 demonstrate that around $55 \%$ of the participants intend to work in private sector after graduating from the management faculty and that they indicated to have one family member who established and managed his/ her business. Rate of participants who are candidate entrepreneurs who want to establish and manage their own business in the future is $69,1 \%$.

\subsection{Definitive Statistics and Internal Consistency Analysis}

The statements in "Entrepreneurship Characteristics" used in the study were arranged according to Likert type scale of 5 and among the average values obtained as a result of analysis of dimensions included in the scales, those which are under 3 stated for negative judgment and those above 3 stated for positive judgment (1:Strongly Disagree .....5:Strongly Agree) The statements in "Type A Personality Structure" scale were arranged according to Likert type scale of 8 and among the average values obtained as a result of analysis of dimensions included in the scales, those which are under 4.5 stated for negative judgment and those above 4.5 stated for positive judgment. Dimension averages demonstrate average, 
arithmetic value in relation to a factor; and standard deviations indicate the status of closeness of responses of individuals to one another. The standard deviation being small indicates that the tendencies among individuals in terms of factors are close (homogenous), and the standard deviation being big indicates that tendencies among responders move away from one another (heterogenous) (Gurbuz, 2006). In short, the fact that the standard deviation is small indicates that deviation from the average is low, and that it is high indicates that deviation from average is high.

Table 4. Definitive Statistics and Findings of Internal Consistency

\begin{tabular}{|l|c|c|c|c|}
\hline Dimensions & Average & $\begin{array}{c}\text { Standard } \\
\text { Deviation }\end{array}$ & $\begin{array}{c}\text { Standard } \\
\text { Error of } \\
\text { Average }\end{array}$ & $\begin{array}{c}\text { Cronbach } \\
\text { Alpha }\end{array}$ \\
\hline $\begin{array}{l}\text { ENTREPRENEURSHIP } \\
\text { (GENERAL) }\end{array}$ & 4,07 & 0,03 & 0,48 & 0,767 \\
\hline Will to succeed & 3,87 & 0,05 & 0,68 & 0,774 \\
\hline Determination & 4,22 & 0,04 & 0,63 & 0,742 \\
\hline Practical intelligence & 4,07 & 0,04 & 0,61 & 0,711 \\
\hline Innovation & 4,42 & 0,04 & 0,65 & 0,828 \\
\hline Independence & 4,08 & 0,05 & 0,74 & 0,657 \\
\hline Self-confidence & 3,53 & 0,06 & 0,94 & 0,635 \\
\hline $\begin{array}{l}\text { TYPE A PERSONALITY } \\
\text { STRUCTURE (GENERAL) }\end{array}$ & 5,12 & 0,06 & 0,98 & 0,691 \\
\hline
\end{tabular}

When we look at Table 5, we see that the average of entrepreneur aspects was 4,06; and the averages pertinent to characteristics related to type A personality structures was 5,1 . It could be seen that the innovation $(4,42)$ and determination $(4,21)$ dimensions among the dimensions pertinent to entrepreneurship were to be highlighted from the point of view of averages.

In this study which was conducted on examining the relationship between type A personality structure and entrepreneurship characteristics, the statements of "Entrepreneurship Characteristics" which comprises 22 statements were prepared in the form of Likert scale of 5, and statements related to "Type A Personality Structure" comprising 7 statements were prepared and directed to the participants on Likert scale of 8 degrees. Statements in the scales in question were subjected to reliability analysis and analysis results related to the internal consistency of the scales were shown in Table 5. The reliability findings of the scales were calculated with reliable values Cronbach Alpha coefficient method for articles which comprises 7-statement scale of type A Personality Structure and articles for each dimension that constitutes entrepreneur characteristics for articles comprises 22statement scale for entrepreneurship characteristics. The fact that the alpha values are between 0,60-0,80 points out that the scale is highly reliable (Özdamar,1999:522).

\subsection{Correlation Analysis}

The basic objective of the research is to test whether there is a relationship between type A personality structure and entrepreneurship characteristics. For that purpose a $\mathrm{H}_{1}$ hypothesis was established which was read as "there is a relationship between type A personality structures of people and entrepreneurship", and a correlation analysis was made in order to determine this relationship and its aspect. 


\section{$\int\left(\begin{array}{c}\text { Journal of Life } \\ \text { Economics }\end{array}\right.$}

Table 6. Correlation Analysis Table

\begin{tabular}{|l|c|c|c|c|c|c|c|}
\hline Dimensions & $\begin{array}{c}\text { Entrep. } \\
\text { Charact. } \\
\text { (General) }\end{array}$ & $\begin{array}{c}\text { Will to } \\
\text { succeed }\end{array}$ & Determination & $\begin{array}{c}\text { Practical } \\
\text { intelligence }\end{array}$ & Innovation & Independence & $\begin{array}{c}\text { Self- } \\
\text { confidence }\end{array}$ \\
\hline $\begin{array}{l}\text { Type A } \\
\text { Personality } \\
\text { Structure }\end{array}$ & $.65 * * *$ & $.55 * * *$ & $.50 * * *$ & $.52 * * *$ & $.40 * * *$ & $.51 * * *$ & $.50 * * *$ \\
\hline
\end{tabular}

*** Significant at $\mathrm{p}<0.001$ level.

According to the results of correlation analysis given in Table 6, there is a significant, positive direction and medium level relationship at $\mathrm{r}=0.65, \mathrm{p}=0,001$ between type $\mathrm{A}$ personality structures of persons and entrepreneurship. These values demonstrate that the $\mathrm{H} 1$ hypothesis of our research, which was "There is a significant relationship between type A personality structures of people and their entrepreneurship characteristics", was accepted. On the other hand, it was concluded that there was a statistically significant, medium level and positive relationship between "practical intelligence" "will to succeed" and "independence" dimensions, which constitute the entrepreneurship, and type A personality, and there was a statistically significant, positive direction and medium level close relationship between "Innovation", "Determination" and "Self Confidence" dimensions and type A personality.

\section{DISCUSSION AND CONCLUSION}

The facts that around 55\% of the participants indicated that they intend to work in the private sector after graduation and therefore a slight more of half of the students want to establish and manage their works, are important as this demonstrate that the sample indicates that they have social entrepreneurship capabilities. In particular, it is an important issue that the students emphasized their social entrepreneurship capabilities during their educational lives. When we evaluate the averages of responses given to statements related to entrepreneurship in the sample, it could be seen that competition with others reflected their styles, that they did not accept someone to play a directive/ leading role in their lives and they were hesitant to listen to the words of those who tell them that they were chasing after nothing. These values are important as these demonstrate that the entrepreneurship capabilities of students are not developed at a promising level. It should be indicated that it is an essential point to emphasize the entrepreneurship capabilities of young people especially during their university education period and to develop these capacities.

When we evaluate the results of the research from the point of type A personality structure, which is another variable of the sample, the examination of the responses given by the students lead to the fact that statements other than the statement "I act carefully as regard my appointments (clothing, timing etc.)" were generally quite close to median and the statements got average values of 4 to 5 or around 5. Taking the average values in question into account and with a general assessment, it is possible say students to participate in the research bear type A personality characteristics. When we evaluate the entrepreneurship aspects of the participants, it was concluded that the entrepreneurship general average was 4,06 , and the innovation $(4,42)$ and determination $(4,21)$ dimension among the dimensions pertinent to entrepreneurship was highlighted in relation to averages.

The basic objective of the research is to test whether there is a relationship between type A personality structure and entrepreneurship characteristics. For that reason the $\mathrm{H}_{1}$ hypothesis which reads "there is a relationship between type A personality structures of 


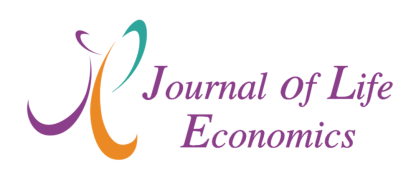

participants and entrepreneurship" was tested. Results of the correlation analysis carried out demonstrate that there is a $\mathrm{r}=0,647, \mathrm{p}=0,001$ level statistically significant, positive direction and medium level relationship between type A personality structure and entrepreneurship. Values obtained as a result of correlation analysis also demonstrate that the $\mathrm{H}_{1}$ hypothesis of the research is accepted. On the other hand, the dimensions of practical intelligence $(\mathrm{r}=0,517$; $\mathrm{p}=0,000)$, will to succeed $(\mathrm{r}=0,547 ; \mathrm{p}=0,000)$ and independence $(\mathrm{r}=0,508 ; \mathrm{p}=0,000)$ which constitute entrepreneurship, have a statistically significant, medium level and positive relationship with type A personality structure. The relationship between innovation $(r=0,398$ $\mathrm{p}=0,000)$ determination $(\mathrm{r}=0,497 ; \mathrm{p}=0,000)$ and self-esteem $(\mathrm{r}=0,501 ; \mathrm{p}=0,002)$ dimensions and type A personality structure was found to be statistically significant, positive direction and medium level, which is important as it demonstrates that the model is correctly established in relation to the research results.

In the literature scanning performed in relation to the research subject, since there were no sufficient number of students which handled the issue of personality characteristics and life satisfaction, it is thought that the research will have a significant contribution for both the academicians and implementers working in this field as well as for the literature and thus it is of importance. For that reason, it is considered that it will be beneficial to emphasize the following issues in the studies to be conducted in the future.

Since the research was conducted on the students of management faculty of a public university, the scope of the study comprises the potential entrepreneur candidates who are being educated in the faculty in question. The facts that the sample of the research comprises the students and easy sampling method was adopted as the sample selection method in the research appear before us as restrictions for generalization of the results. It was assumed that the expressions in the scales were correctly understood and the participants in the research responded in a true manner and that the sample of the research was large enough for statistical analysis on qualitative terms. The findings of the research are confined to the sample and expressions in the questionnaire, and any comment asserted in the research is limited to the participants of the research, the data collection means and those who could be reached among students who are being educated in the university in question.

When the findings of the research are evaluated in general, it could be said that studies taking an account on the entrepreneurship characteristics and personality structures of people should be analyzed in a deeper manner in the future studies and performing researches which includes such socio-economic variables as gender, income status and educational status, which could affect both personality structure and entrepreneurship characteristics, will be beneficial for future.

Dimensioning the characteristics of individuals having type A personality and making measurements with statements that measure each dimension, could make the results to be obtained in the future studies different. Together with this, since individuals who demonstrate type A personality are those who are ego-centric, inpatient, competitive, work-oriented, fast and aggressive individuals, further studies could get important contributions from separate consideration of the dimensions in question from entrepreneur characteristics. 


\section{$\int\left(\begin{array}{c}\text { Journal of Life } \\ \text { Economics }\end{array}\right.$}

\section{REFERENCES}

Ağca V. ve D. Yörük, 2006, Bağımsız Girişimcilik Ve İç Girişimcilik Arasındaki Farklar: Kavramsal Bir Çerçeve, Afyon Kocatepe Üniversitesi, İI.I.B.F. Dergisi, C.8,S.2.

Aksöz, E. O., Adaçay, F. R., Kozak, R., Esen, E. ve H. Bakır, 2012, Dış Ticarette Girişimcilik, Anadolu Üniversitesi Yayını, 1(1), Eskişehir.

Aktaş, A. M., 2001, Bir Kamu Kuruluşunun Üst Düzey Yöneticilerinin İş Stresi ve Kişilik Özellikleri, Ankara Üniversitesi Siyasal Bilgiler Fakültesi Dergisi, Ankara, (8.56):2642.

Akyüz, Kadri Cemil, T. Gedik, A. Aydın, İ. Yıldırım ve İ. Akyüz, 2009, Orman Fakültesi Son Sınıf Öğrencilerinin Meslek Tercihleri Ve Girişimcilik Eğilimleri, Uluslararası Íktisadi İdari Íncelemeler Dergisi, Y11 2, Sayı 1, Ss. 139-158.

Alpkan, L., Keskin, H. ve C. Zehir, 2002, Girişimcilik Hisleriyle Girişimcilik Potansiyeli Arasındaki İlişki: Gebze ve Civarındaki Girişimciler Üzerine Bir Saha Araştırması, 21. Yüzyılda KOBİler: Sorunlar, Fırsatlar ve Çözüm Önerileri Sempozyumu, Doğu Akdeniz Üniversitesi İşletme Fakültesi, K.K.T.C.

Arıkan, S., 2004, Girişimcilik Temel Kavramlar ve Bazı Güncel Konular. Ankara: Siyasal Kitabevi.

Avşar, M., 2007, Yükseköğretimde Öğrencilerin Girişimcilik Eğilimlerinin Araştırılması: Çukurova Üniversitesinde Bir Araştırma, Yayınlanmamış Yüksek Lisans Tezi, Adana: Çukurova Üniversitesi, Sosyal Bilimler Enstitüsü.

Aytaç, T., 2002, Eğitim ve Yönetimde Yeni Yaklaşımlar Zaman Yönetimi, Bilim ve Aklın Aydınlı̆̆ında Ĕ̈itim Dergisi, http://yayim.meb.gov.tr/yayimlar/sayi29/aytac.htm, 24. 05. 2003.

Balaban, Ö. ve Özdemir, Y., 2008, Girişimcilik Eğitiminin Girişimcilik Eğilimi Üzerine Etkisi: Sakarya Üniversitesi İ̈B Örneği, Girişimcilik ve Kalkınma Dergisi, Cilt:3, Say1:2.

Balkıs, M., 2003, Üniversite Öğrencilerinin Düşünme Stilleri İle Kişilik Tipleri Arasındaki İlişkinin Çeşitli Değişkenler Açısından İncelenmesi, Yayınlanmamış Yüksek Lisans Tezi, Dokuz Eylül Üniversitesi Sosyal Bilimler Enstitüsü, İzmir.

Bernstein, A., 2011, Nature vs Nurture: Who is Interested in Entrepreneurship Education? A Study of Bussiness and Technology Undergraduates Based on Social Cognitive Career Theory, Phd, The George Washington University.

Bilge, H. ve V. Bal, 2012, Girişimcilik Eğilimi: Celal Bayar Üniversitesi Öğrencileri Üzerine Bir Araştırma, Süleyman Demirel Üniversitesi, Sosyal Bilimler Enstitüsü Dergisi, 2012/2, Say1. 16, Ss. 131-148.

Binks, M. and P. Vale, 1990, Entrepreneurship and Economic Change. London: McGrawHill Book Company.

Bozkurt, Ç., 2011, Dünyada Ve Türkiye’de Girişimcilik Eğitimi: Başarılı Girişimciler Ve Öğretim Üyelerinden Öneriler, Detay Yayıncılık, Ankara.

Bozkurt Ö. ve K. Erdurur, 2013, Girişimci Kişilik Özelliklerinin Girişimcilik Eğilimindeki Etkisi: Potansiyel Girişimciler Üzerinde Bir Araştırma, Girişimcilik ve Kalkınma Dergisi, 8(2):57-78. 
Bozkurt, Ö., 2006, Girişimcilik Eğiliminde Kişilik Özelliklerinin Önemi, Girişimcilik Ve Kalkınma Dergisi, Cilt 2, Say1 2, ss. 93-111.

Bozkurt, Ö. Ç., Kalkan, A., Koyuncu, O. ve A.M. Alparslan, 2012, Türkiye'de Girişimciliğin Gelişimi: Girişimciler Üzerinde Nitel Bir Araştırma, Journal Of Süleyman Demirel University Institute of Social Sciencesyear, 1(15),ss:230-247.

Brice, J., 2002, The Role Of Personal Dimension And Occupational Preferences On The Formation Of Entrepreneur Intention, Unpublished Doctorate Dissertation, Department Of Management And Information Systems, Mississippi State University.

Brindley, C., 2005, Barriers to Women Achieving Their Entrepreneurial Potential: Women and Risk. International Journal of Entrepreneurial Behaviour \& Research, 11(2): 144-161.

Bygrave, W. ve M. Minniti, 2000, The Social Dynamics Of Entrepreneurship. Entrepreneurship Theory and Practice, 24(3): 25-36.

Cansız, E., 2007, Üniversite Öğrencilerinin Girişimcilik Özelliklerinin Belirlenmesi: Süleyman Demirel Üniversitesi Öğrencileri Üzerine Bir Çalışma, Yayınlanmamış Yüksek Lisans Tezi, Isparta: Süleyman Demirel Üniversitesi, Sosyal Bilimler Enstitüsü.

Ceylan A. ve Demircan N., 2002, Girişimcilerin Başarı, Güç ve Yakın İlişki İhtiyaçlarının Kişilik Özellikleriyle İlişkisi Üzerine Düzce Bölgesi'ndeki KOBİ'lerde Yapılan Bir Araştırma. 21. Yüzyılda KOBI'ler: Sorunlar, Fırsatlar ve Çözüm Önerileri Sетроzуити, Doğu Akdeniz Üniversitesi, http://www.emu.edu.tr/smeconf/turkcepdf/bildiri_21.pdf.

Ceylan, Y., 2012, Zorunlu Göç ve Suç İlişkisi: Muş İli Örneği', Akademik Bakış Dergisi, 32, s.1-18.

Champoux, J. E., 1996, Organizatioanl Behavior, Integrating Individuals Groups and Processes, West Publising Company.

Çarıkçı, İ. H. ve O. Koyuncu, 2010, Bireyci Toplumcu Kültür Ve Girişimcilik Eğilimi Arasındaki İlişkiyi Belirlemeye Yönelik Bir Araştırma, Mehmet Akif Ersoy Üniversitesi Sosyal Bilimler Enstitüsü Dergisi, Y11. 2, Say1. 3, Ss. 1-18.

Doğan, N., 2013, Türkiye'de Girişimcilik Eğilimi: Üniversite Öğrencilerine Yönelik Bir Araştırma, Yayınlanmamış Yüksek Lisans Tezi, İstanbul: İstanbul Üniversitesi.

Doğaner, M. ve A. E. Altunoğlu, 2010, Adnan Menderes Üniversitesi Nazilli İktisadi Ve İdari Bilimler Fakültesi İşletme Bölümü Öğrencilerinin Girişimcilik Eğilimleri, Organizasyon Ve Yönetim Bilimleri Dergisi, Cilt 2, Say1 2, Ss. 103-110.

Durna, U., 2005, A Tipi Ve B Tipi Kişilik Yapıları Ve Bu Kişilik Yapılarını Etkileyen Faktörlerle İlgili Bir Araştırma, İktisadi ve İdari Bilimler Dergisi, Cilt: 19 Nisan 2005 Say1: 1.

Edwars, J, R., A. S. JR. Baglioni and C. L. Cooper, 1990, The Psychometric Properties of The Bortner Type A Scale, British Journal of Psychology. 81.3,15-33.

Ekici, E., 2016, Üniversite Öğrencilerinin Girişimcilik Eğilimini Belirlemede Planlanmış Davranışlar Teorisi Ve Girişimcilik Eğitiminin Rolü, Yayınlanmamış Yüksek Lisans Tezi, Çukurova Üniversitesi Sosyal Bilimler Enstitüsü Yönetim Ve Organizasyon Anabilim Dalı, Adana. 


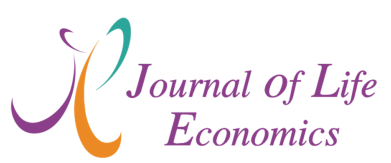

Emsen, Ö., 2001, Genç Nesilde Mesleki Eğilimler ve Girişimcilik: Ampirik Bir Çalışma, MPM Verimlilik Dergisi, 1:153-176.

Erdoğan. Ç. ve B. Zengin, 2012, Turizm Lisans Öğrencilerinin A ve B Tipi Kişilik Özelliklerine Göre Mesleki Yönelimlerinin Belirlenmesi: Sakarya Üniversitesi Örneği, XI. Geleneksel Turizm Paneli, 16 Nisan, Sakarya.

Fidan, Y. ve S. Çiftçi, 2010, Farklı Fakültelerdeki İşletme Öğrencilerinin Girişimciliğe Bakışları, Adıyaman Üniversitesi Sosyal Bilimler Enstitüsü Dergisi, Yı1 3, Sayı 4, Ss. 58-73.

Franco, M., Haase, H. and A. Lautenschläger, 2010, Students' Entrepreneurial Intentions: An Inter-Regional Comparision, Education \& Training, Vol. 52, No: 4, Pp. 260-275.

Friedman, M., and R. H. Rosenman, 1959, Association of Specific Overt Behavior Pattern with Blood and Cardiovascular Findings, Journal of the American Medical Association. 169, 1286-1296.

Güney, S., 2000, Davranış Bilimleri, 2. Baskı., Nobel Yay., Ankara.

Gürbüz S.,2006. Örgütsel Vatandaşlık Davranışı İle Duygusal Bağlılık Arasındaki İlişkilerin Belirlenmesine Yönelik Bir Araştırma, Ekonomik ve Sosyal Araştırmalar Dergisi,3/1: 48-75

Hansemark, O. C., 2000, Predictive Validity of TAT and CMPS on the Entrepreneurial Activity, Start of a New Business: A Longitudinal Study, Journal of Management Psychology, 15(7): 634-654.

Hattab, H. W., 2014, Impact of Entrepreneurship Education on Entrepreneurial Intentions of University Students in Egypt, The Journal of Entrepreneurship, 23(1): 1-18.

Hisrich, R.D. and M.P. Peters (1989) Entrepreneurship: Starting, Developing, And Managing A New Enterprise, Homewood, IL: BPI, Irwin Mcgraw-Hill.

Hisrich, R. D. and M. P. Peters, 1992, Entrepreneurship: Starting, Developing, And Managing A New Enterprise. McGraw-Hill/Irwin.

Ireland, R. D., Hitt, M. A. and D. G. Sirmon, 2003, A Model of Strategic Entrepreneurship: The Construct and Its Dimensions. Journal of Management, 29: 963-989.

İbicioğlu, H., Özdaşlı, K. ve A.M. Alparslan, 2009, Girişimcilik Özellikler ve Girişimcilik Kültürü Tercihi Üzerinde Ebeveyn etkisi: Mehmet Akif Ersoy Üniversitesi Araştırması, Selçuk Üniversitesi Sosyal Bilimler MYO Dergisi, Sayı 1-2, Cilt 12, 521538

İpçioğlu, İ. ve A. Taşer, 2009, İşletme Bölümlerinde Verilen Eğitimin Girişimci Aday1 Öğrenciler Üzerindeki Etkileri. Süleyman Demirel Üniversitesi Sosyal Bilimler Enstitüsü Dergisi, (10), 13-25.

İrmiş, A., 2003, Kırgızistan Bişkekeeteki Üniversite Öğrencilerinin Girişimcilik Eğilimleri Üzerine Yapılan Bir Çalışma, Manas Üniversitesi Sosyal Bilimler Dergisi, 5, ss.13652.

İrmiş, A. ve E. Barutçu, 2012, Öğrencilerin Kendilerini Girişimci Bir Kişiliğe Sahip Görmelerini Ve İş Kurma Niyetlerini Etkileyen Faktörler: Bir Alan Araştırması, Atatürk Üniversitesi İktisadi Ve İdari Bilimler Dergisi, Cilt 26, Sayı 2, Ss. 1-25 


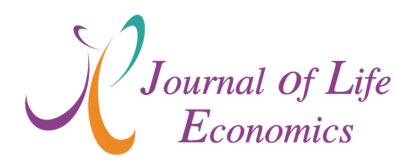

İşcan Ö. F. ve E. Kaygın, 2011, Üniversite Öğrencilerinin Girişimcilik Eğilimlerini Belirlemeye Yönelik Bir Araştırma. Atatürk Üniversitesi Sosyal Bilimler Enstitüsü Dergisi, 15 (2): 443-462.

Karahan, M. ve İ. Ulusoy, 2010, Hatay İli Girişimcilik Özelliklerinin İncelenmesi, EKEV Akademi Dergisi, Cil:14, Sayı:1 ss:367-379.

Karasakal, N. K., Aksu, B. ve R. Demircili 2013, Meslek Yüksekokullarındaki Teknik ve Sosyal Program Öğrencilerinin Girişimci Kişilik Açısından Karşılaştırılarak Program Türünün Girişimciliğe Özendirme ve Girişimci Kişilik Oluşumu Konusunda Bir Etkisinin Olup Olmadığını Tespit Etmeye Yönelik Bir Alan Araştırması. Organizasyon ve Yönetim Bilimleri Dergisi, 5(2):134-150.

Keleş, H. N, Özkan, T. K., Doğaner, M. ve A. E. Altunoğlu, 2012, Ön Lisans Öğrencilerinin Girişimcilik Düzeylerini Belirlemeye Yönelik Bir Araştırma, Uluslararası İktisadi Düşünceler Dergisi, Cilt:5, Sayı:9,ss:107-118.

Kılıç, R., Keklik, B. ve N. Çalış, 2012, Üniversite Öğrencilerinin Girişimcilik Eğilimleri Üzerine Bir Araştırma: Bandırma İ̈BF İşletme Bölümü Örneği, Süleyman Demirel University Journal Of Faculty Of Economics \& Administrative Sciences, 17(2).

Koh, H. C., 1996, Testing Hypotheses of Entrepreneurial Characteristics A Study of Hong Kong MBA Students, Journal of Managerial Psychology, 11(3): 12-25.

Lee J.-S. and C.-J. Hsieh, 2010, A Research in Relating Entrereneurship, Marketing Capability, Innovative Capability and Sustained Competitive Advantage. Journal of Business-Economics Research, 8(9): 109-119.

Lelord. F., ve Andre, C., 1996, Zor Kişilikler"le Yaşamak (Çev. R Madenci), İstanbul: İletişim Yayınları.

Linan, F., Rodriguez-Cohard, J. C. and J. M. Rueda-Cantuche, 2011, Factors Affecting Entrepreneurial Intention Levels: A Role For Education, International Entrepreneurial Management Journal, (7): 195-218.

Noruzi, M. R., Westover, J. H. and G. R. Rahimi, 2010, An Exploration of Social Entrepreneuship in the Entrepreneuship Era, Asian Social Science, 6(6):3-10.

Onur, B. (1997), Gelişim Psikolojisi, İmge Kitabevi Yayınları, Ankara.

Orman, S., 2009, Factors Affecting Entrepreneurial Intentions: An Application For University Students And University Graduates Employees, Yayınlanmamış Yüksek Lisans Tezi, Marmara Üniversitesi, Sosyal Bilimler Enstitüsü.

Ören K.ve Biçkes M., 2011, Kişilik Özelliklerinin Girişimcilik Potansiyeli Üzerindeki Etkileri: Nevşehir'deki Yüksek Öğrenim Öğrencileri Üzerinde Yapılan Bir Araştırma. Süleyman Demirel Üniversitesi İktisadi ve İdari Bilimler Fakültesi Dergisi, 16(3): 6768.

Örücü, E., Kılıç, R. ve Ö. Yılmaz, 2007, Üniversite Öğrencilerinin Girişimcilik Eğilimlerinde Ailesel Faktörlerin Etkisi Üzerine Bir Uygulama, Girişimcilik Ve Kalkınma Dergisi, Cilt 2, Sayı 2, Ss. 27-47.

Özdamar, K., 1999, Paket Programlar ile İstatistiksel Veri Analizi, Kaan Kitabevi, Eskişehir.

Özdemir, A., Saygıll, M. ve K. Yıldırım, 2016, Risk Alma Eğilimi ve Başarma İhtiyacının Girişimcilik Potansiyeline Etkisi: Üniversite Öğrencileri Üzerine Bir Araştırma, The Journal of Business Science, Cilt:4, Sayı:2, ss.121-141. 


\section{$\int\left(\begin{array}{c}\text { Journal of Life } \\ \text { Economics }\end{array}\right.$}

Ronstadt, R. C. (1984). Entrepreneurship: Text, Cases, and Notes, Lord Publishing.

Seydinbekuli, A. D., Abishov, N. ve Y. Yılmaz, 2015, Üniversite Son Sınıf Öğrencilerinin Girişimcilik Eğilimlerinde Ailesel Özelliklerin Etkisi: Ahmet Yesevi Uluslararası Türk-Kazak Üniversitesinde Bir Alan Araştırması, Avrasya Uluslararası Araştırmalar Dergisi, 3(6), ss:44.

Shane, S. and S. Venkataraman, 2000, The Promise Of Entrepreneurship as A Field of Research, Academy of Management Review, Vol:25, No:1, pp,217-226.

Sinha, T. N., 1996, Human Factors In Entrepreneurship Effectiveness, The Journal of Entrepreneurship, 5(1):23-39.

Solmaz, S.A., Aksoy, Ö., Şengül, S. ve M. Sarışık, 2014, Üniversite Öğrencilerinin Girişimci Kişilik Özelliklerinin Belirlenmesi: Turizm Lisans Ve Önlisans Öğrencileri Üzerine Bir Alan Araştırması, KMÜ So yal ve Ekonomik Araştırmalar Der $i \llbracket i, 16$ (26): 41-55.

Stevenson, H. H., Roberts M., Grousbeck J., Harold I. I. and A. Bhide,1985, New Business Ventures And The Entrepreneur (2nd ed.), Homewood, Ill.: R.D. Irwin.

Summers, D., 1998, An Emprical Investigations Of Personal And Situational Factors That Relate To Formation Of Entrepreneur Intensions, Unpublished Doctorate Dissertation, Texas Universty, P.1-189.

Titiz, T., 1999, Genç Girişimcilere Öneriler. İstanbul: İnkılap Kitabevi.

Top, S., 2006, Girişimcilik Keşif Süreci. İstanbul: Beta Basım Yayım.

Tutar, H., 2013, Davranış Bilimleri Kavramlar ve Kuramlar, Seçkin Yayıncılık, Ocak, 1. Bask1,

Tutar, H., 2015, Mobbing (Nedenleri ve Başa Çıkma Stratejileri: Kuramsal Yaklaşım), Detay Yayınc1lı, 1.Bask1.

Wang, C. K. and P. K. Wong, 2004, Entrepreneurial Interest Of University Students in Singapore, Technovation, (24): 163-172.

Yalçıntaş, M., 2007, KOBİ'ler ve Girişimcilik. Girişimcilik ve Kalkınma Dergisi, 2(2):145 148.

Yıldırım, M. H., Demirel, Y., ve L. İçerli , 2011, İşletme Sahibi Yöneticilerin Girişimci Kişilik Özellikleri İle Girişimcilik Becerileri Arasındaki İlişkinin Tespiti: Aksaray Örneği. Organizasyon ve Yönetim Bilimleri Dergisi,3(2): 189-199.

Yıldız, G. ve E. Özsoy, 2013, Çalışanların Kişilik Özelliğine Göre İş Doyumu Farklılaşır Mı? Sosyal Ve Beşeri Bilimler Dergisi (Online), Cilt 5, No 1, ss.268-278.

Yılmaz, E. ve A. Sünbül, 2009, Üniversite Öğrencilerine Yönelik Girişimcilik Ölçeğinin Geliştirilmesi, Selçuk Üniversitesi Sosyal Bilimler Enstitüsü Dergisi, 21(1), ss:195203.

Yurtsever, H. (2009)."Kişilik Özelliklerinin Stres Düzeyine Etkisi Ve Stresle Başa Çıkma Yolları: Üniversite Öğrencileri Üzerine Bir Araştırma", Yayınlanmamış Yüksek lisans Tezi, Dokuz Eylül Üniversitesi, S.B.E., İzmir. 